J. Clin. Chem. Clin. Biochem.

Vol. 19, 1981, pp. 81-87

\title{
Specific Quantitation by HPLC of Protein (Lysine) Bound Glucose in Human Serum Albumin and Other Glycosylated Proteins
}

\author{
By E. Schleicher and $O$. H. Wieland
}

Klinisch-chemisches Institut und Forschergruppe Diabetes, Städtisches Krankenhaus München-Schwabing

(Received March 31/July 28, 1980)

Summary: A specific and sensitive method for quantification of the fructose-lysine linkages present in nonenzymatically glycosylated albumin and other proteins is described. Protein is hydrolyzed for $18 \mathrm{~h}$ in $6 \mathrm{~mol} / 1 \mathrm{HCl}$ at $95^{\circ} \mathrm{C}$ to yield furosine ( $\epsilon$-N-(2-furoylmethyl)- $L$-lysine) known as a specific degradation product of fructose-lysine. Furosine is then separated on HPLC and quantified by its UV-absorbance against a prepared fructose-lysine standard. The method has been successfully used for the determination of glycosyl-albumin in diabetic patients starting from $100 \mu \mathrm{l}$ serum or less, as well as for various other proteins. Unlike the usually employed thiobarbituric acid assay the present procedure is truly specific for the detection of ketoamine linkages of glycosylated proteins.

\section{Spezifische Bestimmung von Protein (Lysin)-gebundener Glucose in Serumalbumin des Menschen und anderen glycosylierten Proteinen durch Hochdruckflüssigchromatographie}

Zusammenfassung: Es wird eine spezifische und empfindliche Methode zur Bestimmung der Fructose-Lysinbindungen von nichtenzymatisch glycosyliertem Albumin und anderen Proteinen beschrieben. Sie beruht auf der Hydrolyse des Proteins für 18 Stunden in $6 \mathrm{~mol} / 1 \mathrm{HCl}$ bei $95^{\circ} \mathrm{C}$, wobei als spezifisches Abbauprodukt des Fructose-Lysins Furosin ( $\epsilon$-N-(2-Furoylmethyl)-L-lysin) entsteht. Furosin wird dann durch HPLC abgetrennt und durch UV-Absorption gegen einen selbstsynthetisierten Fructose-Lysinstandard gemessen. Die Methode eignet sich für die Bestimmung von glycosyliertem Albumin bei Diabetikern, ausgehend von $100 \mu \mathrm{l}$ Serum und weniger, sowie auch allgemein für das Studium glycosylierter Proteine. Sie ist spezifischer als der häufig gebrauchte Thiobarbitursäure-Test, indem sie ausschließlich die Ketoaminbindungen glycosylierter Proteine erfaßt.

\section{Introduction}

The chemical reaction of reducing sugars with amino acids resulting in stable ketoamine adducts was first described by Maillard (1) and has since become a major investigational problem in food processing technology. With the discovery of a glucose adduct of haemoglobin $\left(\mathrm{Hb} \mathrm{A}_{1 \mathrm{c}}\right)$ in normal human erythrocytes (2) it became apparent that nonenzymatic attachment of sugars to amino groups of proteins does not only occur under artificial conditions, but also physiologically in the living organism. The later finding that there is an increase of this glycosylated haemoglobin in the erythrocytes of diabetic patients (3) has greatly stimulated further research in this field. More recently, serum albumin has been shown to undergo a similar reaction with glucose yielding a stable glycosylated form of albumin $(4-10)$ which is also elevated in human diabetics $(7-10)$ and in diabetic rats (6). These and other observations suggested the interesting possibility that increased sugar adduction to macromolecules is a more generalized phenomenon in diabetes mellitus which may have pathophysiological implications in the development of diabetic microangiopathy and other late complications of the disease. The recent finding of glycosylation of the lens crystallins which alters their physical properties and has been implicated to be involved in diabetic cataract formation (11) appears of interest in this context. Further examples of nonenzymatic protein glycosylation are listed in table 1.

Chemically, the first reaction in the glycosylation of proteins is the formation of a Schiff base between the carbonyl group of an aldose or a ketose and the $\mathrm{NH}_{2}$ group of an amino acid. The resulting aldimine linkage may then undergo isomerisation by the so called Amadori rearrangement (17) yielding the corresponding ketoamine compound. As the latter reaction seems hardly reversible under physiological conditions and so far no enzyme is known for the cleavage of the keto- 
Tab. 1. Nonenzymatically glycosylated proteins.

\begin{tabular}{lll}
\hline Protein & Functional change & Ref. \\
\hline Haemoglobin & $\begin{array}{l}\text { Increased oxygen } \\
\text { binding }\end{array}$ & 3,12 \\
$\begin{array}{l}\text { Lens crystallins } \\
\text { Insulin }\end{array}$ & $\begin{array}{l}\text { Loss of transparence } \\
\text { Decrease in biological } \\
\text { activity }\end{array}$ & 11 \\
Serum albumin & not known & $4-10$ \\
$\begin{array}{l}\text { Other serum proteins } \\
\text { Erythrocyte membrane } \\
\text { protein }\end{array}$ & not known & 5,7 \\
Collagen (skin, aorta) & not known & 14 \\
\hline
\end{tabular}

amino linkage, these adducts once formed show very great stability. A general reaction scheme is illustrated in figure 1.

The site of glucose adduction in the glycohaemoglobin fractions $\mathrm{HbA}_{\mathrm{Ia}, \mathrm{b}, \mathrm{c}}$ is the amino group of the terminal valine of the $\beta$-chains (18). Recent studies revealed that there is also glycosylation of the major haemoglobin fraction $A_{\text {II }}$ and that the glucose is bound here to $\epsilon$-amino groups of lysine (19). Present available evidence suggests that the $\epsilon$-amino groups of lysine residues and the N-terminal amino acids are a preferred locus for nonenzymatic attachment of hexoses to proteins.

The discovery by Gottschalk that N-substituted fructoseamines yield 5-hydroxymethylfurfuraldehyde upon mild acid treatment ( $2 \mathrm{~mol} / \mathrm{l}$ acetic acid) (20) provided a clue for the detection of these compounds in natural products. A spectrophotometric method was then developed by Keeney \& Basette (21) in their studies on the browning reaction in milk products using the 2-thiobarbituric acid reaction product of 5-hydroxymethylfurfuraldehyde after hydrolysis with oxalic acid. This assay was applied also for the determination of the glycosylated haemoglobins (22) and is now widely employed for the quantification of nonenzymatically glycosylated proteins.

Although the 2-thiobarbituric acid test is commonly considered specific for ketoamine linkages within glyco-

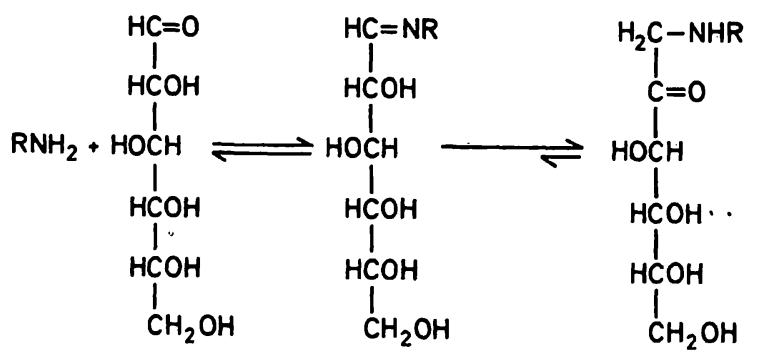

Amine Glucose 1-Imino-1-deoxyglucose 1-Amino-1-deoxyfructose (Aldimine) (Ketoamine)

Fig. 1. General reaction scheme of the addition of glucose to an amino-group, showing formation of a Schiff base and the subsequent $A$ madori rearrangement which yields a stable ketoamine linkage. sylated proteins it is not known whether and to what extent other types of carbohydrate linkages in glycoproteins contribute to 5-hydroxymethylfurfuraldehyde formation under these conditions. We were therefore interested in another procedure which might allow a more specific quantitation of ketoamine linkages in glycosylated body proteins. Again in dairy research it was observed that upon hydrolysis of industrial milk products an unknown lysine derivative is formed in appreciable amounts $(\sim 30 \%)(23)$. This was identified as the hydrolysis product of fructose-lysine, $\epsilon-\mathrm{N}-(2$ furoylmethyl)- $L$-lysine, called furosine $(24,25)$. The hydrolysate also contained about $10 \%$ of another product, $\epsilon$-(3-hydroxy-4-oxo-6-methyl-1-pyridinyl)- $L$ norleucine, called pyridosine (26) (fig. 2). In the present work we report a sensitive and specific method for the determination of glycosylated albumin in human serum which is based on the formation of furosine after hydrolysis of purified albumin in $6 \mathrm{~mol} / 1 \mathrm{HCl}$. Furosine (and pyridosine) is then determined by HPLC. This method is applicable quite generally for the quantitive determination of fructose-lysine linkages in proteins and may therefore deserve special interest for future research into the possible significance of protein glycosylation, in particular with respect to the pathogenesis of the diabetic late complications.

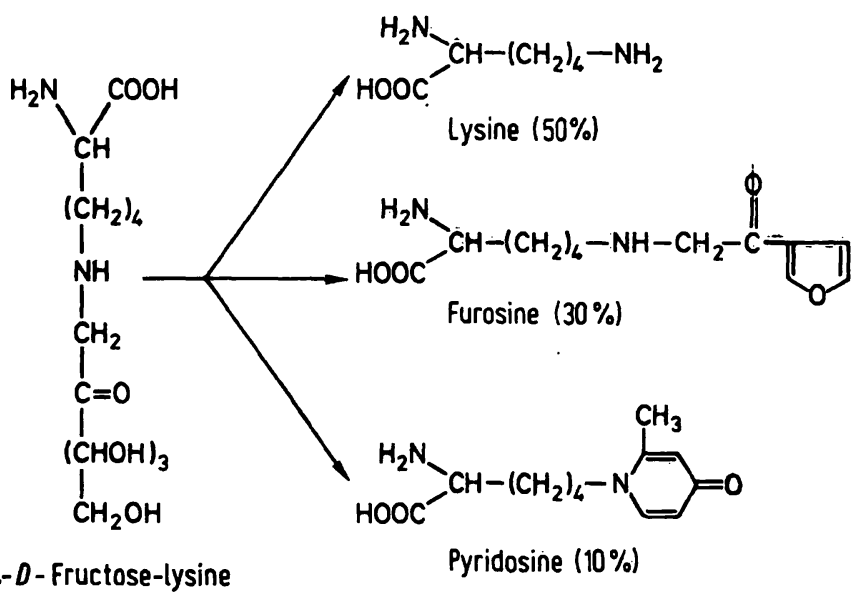

Fig. $2.6 \mathrm{~mol} / 1 \mathrm{HCl}$ hydrolysis of $\epsilon-\ddot{D}$-fructose-lysine gives rise essentially to the three products: lyșine, furosine and pyridosine. Yields shown in brackets (According to l.c. (27)).

\section{Materials and Methods}

\section{Chemicals}

Lyophilized human albumin, reagent grade was purchased from Behring Corp., Marburg, GFR. Cellogel blocks from Chemetron, Milano, Italy were obtained via Serva, Heidelberg, GFR cat. nọ. 44225. The globulin fractions from human serum, $\alpha, \beta$ and $\gamma$ corresponding to Cohn-fraction IV, III and II respectively; were also from Serva Heidelberg. $D-\left[U-1^{14} C\right] g l n c o s e$ was purchased from the Radiochemical Centre Amersham, Braunschweig, GFR. NCS Tissue Solubiliżer was from Amersham/Searle, Heusenstamm-TLC-plates ( $20 \times 20 \mathrm{~cm}$ silicagel, $0.25 \mathrm{~mm}$ thíck), Na- 
Veronal, Veronal and all other standard laboratory reagents were from Merck, Darmstadt, GFR.

Fructose-lysine was prepared essentially according to Brandt (27). Prior to glucosylation, the $\alpha$-amino group of lysine was protected by formylation according to Hofman (28). $400 \mathrm{mg}$ $\mathrm{N}$-formyl-lysine recrystallized from absolute ethanol and $5 \mathrm{~g}$ glucose were refluxed 8 hours in $100 \mathrm{ml}$ absolute methanol at $60^{\circ} \mathrm{C}$ and the solvent removed by vacuum distillation. To remove the formyl group, the residue was dissolved in $10 \mathrm{ml}$ $1 \mathrm{~mol} / 1 \mathrm{HCl}$ and heated for $15 \mathrm{~min}$ on a boiling water bath. The slightly brown product was applied to a column $(15 \times 1.5$ $\mathrm{cm})$ filled with Dowex $15 \mathrm{~W} \times 8$ (200-400 mesh), washed with $50 \mathrm{ml} \mathrm{H}_{2} \mathrm{O}$ and eluted with $0.5 \mathrm{~mol} / \mathrm{l}$ pyridinium acetate $\mathrm{pH}=4.35$. Fractions of $2 \mathrm{ml}$ each were collected. To detect the fructo se-lysine, samples from each fraction were spotted on a TCL-plate and developed in butanol: acetic acid: water $=80$ $\mathrm{ml}+20 \mathrm{ml}+20 \mathrm{ml}$. The amino acids were visualized by ninhydrin. The $R_{\mathrm{f}}$-values for lysine and fructose-ly sine were 0.05 and 0.10 , respectively. The fractions $12-14$, containing only fructose-lysine, were combined and lyophilized. The yield was $17 \%$. A reference sample of fructose-lysine, a gift from Prof. Erbersdobler, Institut für Phy siologie, physiologische Chemie und Ernährungsphysiologie, Fachbereich Tiermedizin, Universität München, migrated with the same $R_{\mathrm{f}}$-value.

\section{Chromatographic system}

We used a model 6000 A Solvent Delivery System, Model U6K Universal Injector and Model 440 Absorbance Detector (all from Waters Associates, Inc. Milford, MA 01757). The prepacked column was a $30 \mathrm{~cm} \times 3.9 \mathrm{~mm}$ " $\mu$ Bondapak $\mathrm{C}_{18}$ ", average particle size $10 \mu \mathrm{m}$ (Waters Associates, Inc.) and a $5 \mu \mathrm{C}_{18}$-column $(20 \times 4 \mathrm{~mm})$ from Macherey and Nagel (Düren, GFR). The eluents were filtered through a glass filter (pore size $0.5 \mu \mathrm{m}$; Millipore Corp., Bedford, MA 01730) and then degassed under reduced pressure for 30 minutes prior to use. Absorption was recorded simultaneously at 280 and 254 $\mathrm{nm}$ by arranging two cuvettes in tandem. Detector sensitivity was set at AUFS $=0.01$. Peak heights at 280 and $254 \mathrm{~nm}$ were recorded on a $10 \mathrm{mV}$ potentiometric dual channel chart recorder. 5-20 $\mu \mathrm{l}$ samples were injected and developed with $7 \mathrm{mmol} / 1 \mathrm{H}_{3} \mathrm{PO}_{4}$ on a $\mu$ Bondapak $\mathrm{C}_{18}$-column at a flow rate of $1 \mathrm{ml} / \mathrm{min}$ (System A). For the $5 \mu \mathrm{C}_{18}$-column the eluent was $5.6 \mathrm{mmol} / 1 \mathrm{H}_{3} \mathrm{PO}_{4}$ (System B). At a chart speed of 0.5 $\mathrm{cm} / \mathrm{min}$ furosine eluted as a sharp peak after 3-3.4 min, tyrosine after ca. $9 \mathrm{~min}$, and phenylalanine after ca. $14 \mathrm{~min}$. All separations were performed at room temperature.

\section{Standard solution}

$29.25 \mu \mathrm{mol}$ fructose-lysine was dissolved in $10 \mathrm{ml} 6 \mathrm{~mol} / \mathrm{l}$ $\mathrm{HCl}$ and hydrolyzed for 18 hours at $95^{\circ} \mathrm{C}$ (Eppendorf thermoblock). After evaporation of the $\mathrm{HCl}$ in vacuo the residue was dissolved in $1 \mathrm{ml} \mathrm{H}_{2} \mathrm{O}$, and 5-25 $\mu \mathrm{l}$ were applied to the HPLC (System B).

Isolation of human serum albumin by preparative electrophoresis has been described elsewhere (8). The albumin preparations were checked by immunoelectrophoresis (29) and shown to contain only traces, if any, of contaminating proteins. Protein was determinêd according to Bradford (30).

\section{In vitro incorporation of $D-[U-14 C]$ glucose into human serum} albumin

$10 \mathrm{ml}$ of a solution of $250 \mathrm{mg} D-\left[\mathrm{U}^{14} \mathrm{C}\right]$ glucose containing $3.03 \mathrm{GBq} / \mathrm{mol}$ was added to $150 \mathrm{mg}$ purified human albumin dissolved in $90 \mathrm{ml}$ Earle's medium (31). After adjusting the $\mathrm{pH}$ to 7.5 by gassing with $95 \% \mathrm{O}_{2} / 5 \% \mathrm{CO}_{2}$, the mixture was incubated at $37^{\circ} \mathrm{C} .10 \mathrm{mg} \mathrm{NaN}$ i was added to prevent growth of microorganisms. Glucose incorporation was followed by mixing $25 \mathrm{ml}$ samples with $5 \mathrm{ml} 3 \mathrm{~mol} / 1$ trichloroacetic acid, washing the precipitate twice with $0.6 \mathrm{~mol} / 1$ trichloroacetic acid, and hydrolysis of the precipitate in $6 \mathrm{~mol} / \mathrm{i} \mathrm{HCl}$ as described previously. After injection of $20 \mu$ of the hydrolysate for HPLC (System A) fractions were collected and counted for radioactivity in a Packard Tricarb Model 2660.

$\mathrm{NaBH}_{4}$ reduction was carried out for $18 \mathrm{~h}$ at room temperature after adding $7 \mathrm{mg} \mathrm{NaBH}$ to a șolution of $15 \mathrm{mg}$ human serum. albumin in $2 \mathrm{ml}$ Earle's medium. The samples were precipitated with trichloroacetic acid and further treated with $6 \mathrm{~mol} / 1 \mathrm{HCl}$ as described previously. All statistical data were computed with Student's t-test (32).

\section{Results}

\section{Calibration curves and sensitivity}

As illustrated in figure 3 there is a linear relationship between furosine formation (peak height) and varying concentrations of fructose-lysine used as standard. The appearance of the furosine peak on HPLC is shown on the insert of figure 3. To detect substances possibly interfering with the furosine peak we always recorded the ratio of the peak heights $A_{280 \mathrm{~nm}} / \mathrm{A}_{254 \mathrm{~nm}}$ and found a constant value of 3.9 for furosine and of 1.2 for pyridosine.

Further proof that we determined only fructoselysine was achieved by reducing human albumin with $\mathrm{NaBH}_{4}$ prior to hydrolysis. Thereby the double bonds of the keto-group are reduced and no furosine and pyridosine could be found after hydrolysis.

Recovery of furosine was studied by adding fructoselysine (29 and $58 \mathrm{nmol}$ respectively) to $1 \mathrm{mg}$ of human serum albumin (Behring) before hydrolysis. Another sample (29 nmol fructose-lysine) hydrolyzed without albumin served as standard. $79.9 \%$ of the added fructoselysine was recovered as furosine in these experiments.

\section{Stability}

Serum samples stored at $-20^{\circ} \mathrm{C}$ showed no changes in the fructose-lysine content of the albumin up to 3 months.

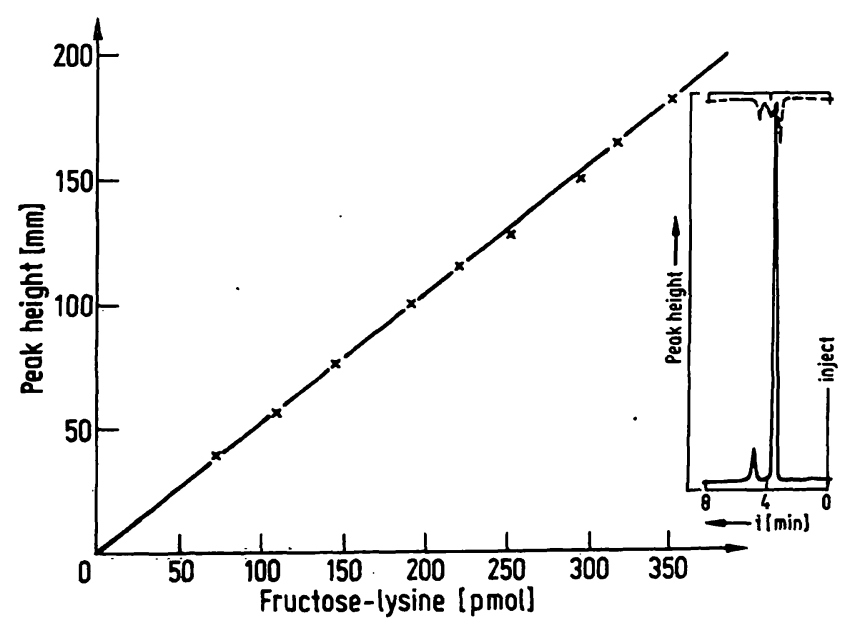

Fig. 3. Standard curve of fructose-lysine analysed by HPLC as furosine and quantified from the height of the absorption peak at $280 \mathrm{~nm}$. Insert: Chromatogram of $0.37 \mathrm{nmol}$ fructose-lysine recorded at 254 and $280 \mathrm{~nm}$ absorbance. Conditions as described in Materials and Methods (HPLCSystem B). 


\section{Precision}

The precision of furosine determination was assessed on a human pool serum. The within run precision yielded a mean value of $0.722 \mathrm{nmol}$ fructose-lysine/nmol albumin, coefficient of variation $=2.94 \%,(n=12)$. The day to day precision from 20 determinations of the pool serum yielded a mean value of $0.715 \mathrm{nmol}$ fructose-lysine/nmol albumin and a coefficient of variation of $8.4 \%$.

In addition to furosine, tyrosine and phenylalanine can be measured by HPLC in the hydrolysates. The dependency of the peak heights $A_{280} \mathrm{~nm}$ and $A_{254} \mathrm{~nm}$ of tyrosine, furosine and phenylalanine on the amounts of albumin is illustrated in figure 4. Accordingly, either of the amino acids representative of the protein content of the sample can be used for internal standardisation.

In the experiments of table 2 in vitro glycosylation of purified human serum albumin was studied using ${ }^{14} \mathrm{C}$ labelled glucose. As expected there was a time dependent increase of the amount of furosine determined by peak heights, and also of ${ }^{14} \mathrm{C}$-radioactivity of the furosine fractions.

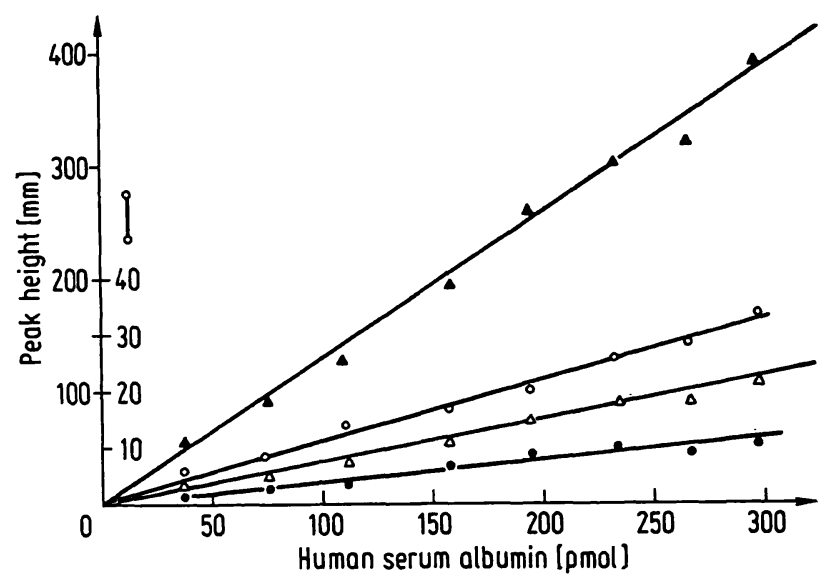

Fig. 4. Standard curve of human albumin: 7-60 nmol of electrophoretically purified serum albumin were hydrolysed as described and $5 \mu$ lof the hydrolysate were chromatographed on HPLC System B. Peak heights of phenylalanine $(\bullet-\bullet, \lambda=254 \mathrm{~nm})$, furosine $(0-0, \lambda=280 \mathrm{~nm})$ and tyrosine $(\Delta \longrightarrow \Delta, \lambda=254 \mathrm{~nm} ; \triangle \longrightarrow \Delta, \lambda=280 \mathrm{~nm})$ are shown.

Tab. 2. In vitro glycosylation of human serum albumin with $D-\left.\right|^{14} \mathrm{C}$-U]gluose. $150 \mathrm{mg}$ albumin were incubated for the times indicated. For further details see Materials and Methods. The value of furosine/tyrosine at zero time is due to endogenous fructose-lysine in the albumin preparation. $\mathrm{cpm}=$ counts $/ \mathrm{min}$

\begin{tabular}{lll}
\hline $\begin{array}{l}\text { Incubation } \\
\text { time (hours] }\end{array}$ & $\begin{array}{l}{ }^{14} \mathrm{C}-\text { Glucose } \\
\text { cpm/mg albumin }\end{array}$ & $\begin{array}{l}\text { ratio } \\
\text { furosine/tyrosine }\end{array}$ \\
\hline 0 & - & 0.37 \\
4 & 473 & 0.42 \\
6 & 632 & 0.44 \\
24 & 1203 & 0.49 \\
48 & 1496 & 0.54 \\
\hline
\end{tabular}

Previous studies from this laboratory $(7,8)$, confirmed by others $(10)$, have shown that there is a marked elevation of glycosylated albumin in the serum of diabetic patients as compared to non diabetic subjects. In these studies glycosylated albumin was determined spectrophotometrically by the condensation product of hydroxymethylfurfural with thiobarbituric acid as outlined in the introduction. As illustrated in figure 5 the elevation of glycosyl-albumin in diabetes can also be demonstrated by means of furosine determination. If one compares the HPLC pattern of albumin of a normal serum (fig. 5A) and of albumin of a diabetic patient (fig. 5B) there is a large increase of the furosine peak in the latter. Quantitatively this corresponds to 0.28 and $0.57 \mathrm{~mol}$ fructose-lysine per mol albumin in the normal and the diabetic serum, respectively.

\section{Specificity of the furosine assay for sugar ketoamine linkages}

Our $\mathrm{NaBH}_{4}$ experiments provided strong evidence that furosine formation depends essentially upon the existence of the sugar ketoamine configuration of glycosylated albumin. In order to examine whether this also holds for other proteins (glycoproteins), which contain the major part of the carbohydrate not in ketoamine-linked form, we have subjected a variety of serum protein fractions to $\mathrm{NaBH}_{4}$ reduction prior to furosine determination. In these studies we

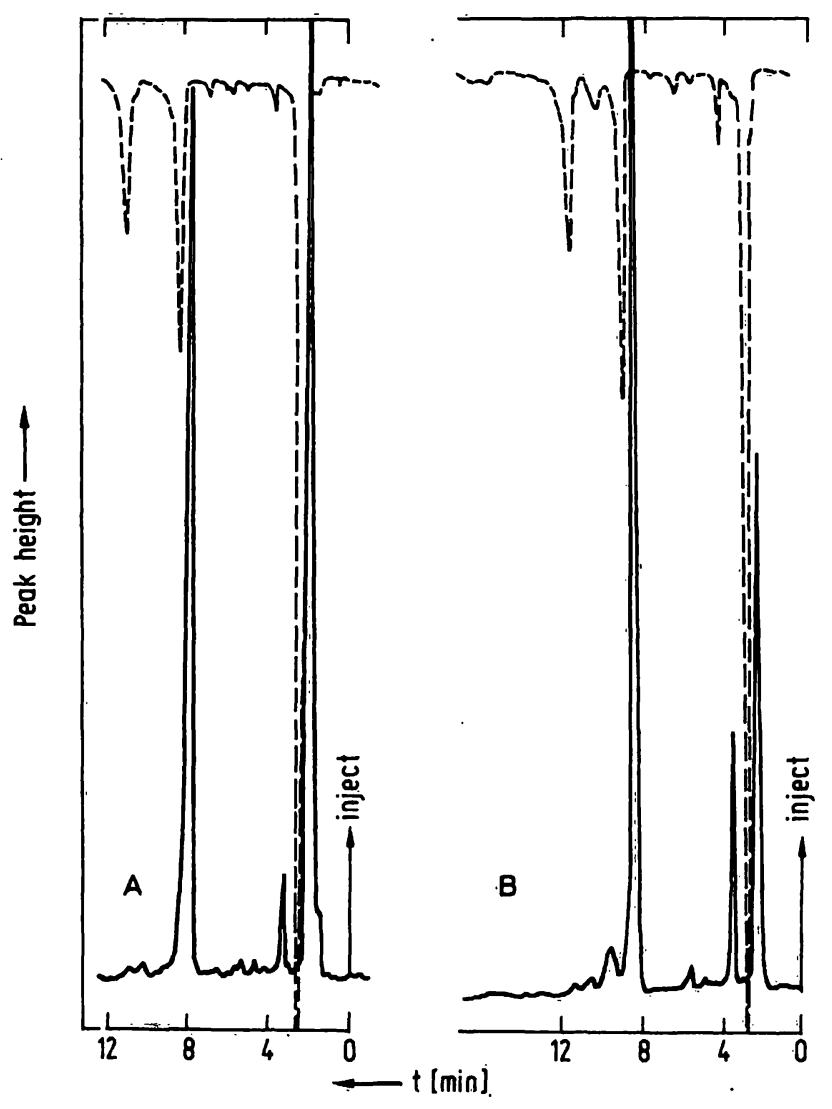

Fig. 5. Chromatograms of two hydrolysed human serum albumins purified by celloblock electrophoresis. A: normal person, B: diabetic patient. Chromatography on HPLC system $\vec{B}$. 
have also measured in parallel the formation of 5 -hydroxymethylfurfuraldehyde which is generally assumed to be specific for the quantitation of ketoamine linkages in glycosylated proteins. The results are summarized in table 3 . From both the furosine and 5-hydroxymethylfurfuraldehyde data of the nonreduced, native proteins it is clear that not only albumin but also the other serum proteins - in particular the $\alpha$-globulins - contain sugar in ketoamine form. This confirms earlier observations $(5,7)$. After reduction furosine is below the detection limits of the method, even in the carbohydrate-rich serum globulins including purified transferrin with a total carbohydrate content of $5.9 \%$ (33). In contrast, quite appreciable amounts of 5-hydroxymethylfurfuraldehyde were still demonstrable after $\mathrm{NaBH}_{4}$ treatment which must have come from nonreducible carbohydrate bonds of the glycoproteins. Thus the 5-hydroxymethylfurfuraldehyde assay appears only partially specific for the determination of ketoamine linked sugars and should therefore be used with precaution for studies of nonenzymatic protein glycosylation.

In these experiments we have determined 5-hydroxymethylfurfuraldehyde by two different methods, e.g. colorimetrically with thiobarbituric acid (42) or by UV absorption of 5-hydroxymethylfurfuraldehyde after separation on HPLC (8). The data agreed quite well in two cases, but much higher values were obtained with the 2-thiobarbituric acid test for the other proteins (tab. 3). This also applies for whole serum where the 2-thiobarbituric acid test still yielded some $50 \%$ of 5 -hydroxymethylfurfuraldehyde after reduct ${ }^{2}$ in with
$\mathrm{NaBH}_{4}$, whereas furosine was below detection level (data not shown). We believe that the 2-thiobarbituric acid test is less reliable due to the very high blank values which are eventually obtained after hydrolysis. As table 3 further shows, the recovery of 5-hydroxymethylfurfuraldehyde from glycosylated proteins is much lower than that of furosine. Taking the 5-hydroxymethylfurfuraldehyde values determined by HPLC, they are roughly ten times lower than the fructose-lysine values both expressed as $\mathrm{nmol} / \mathrm{mg}$ protein.

\section{Discussion}

Further research on non-enzymatic glycosylation of proteins depends to a great extent on the development of analytical procedures for specific and sensitive quantification of glycosylated proteins. In the case of $\mathrm{HbA}_{\mathrm{Ia}-\mathrm{c}}$ the attachment of glucose to the amino groups of valine of the $\beta$-chains alters the charge of the molecules in such a way that they can be easily separated by ion exchange chromatography or by isoelectric focusing (34). Although very useful for routine work these methods cannot be considered sufficiently specific; for instance, on column chromatography $\mathrm{HbF}$ emerges at the same position as $\mathrm{Hb}_{\mathrm{Ic}}$ (35). The possibility of an immunological approach to the quantification of glycosylated proteins is suggested by the report of antibodies for $\mathrm{Hb}_{\mathrm{Ic}}$ determination (36).

Other procedures for measurement of glycosylated proteins are based on the chemical properties of the keto-

Tab. 3. Comparison of the furosine and the 5-hydroxymethylfurfuraldehyde method.

The proteins (about $6 \mathrm{mg}$ ) were dissolved in $2 \mathrm{ml} 0.01 \mathrm{~mol} / 1 \mathrm{~K}$-phosphate buffer $\mathrm{pH}=7.8$ containing $9 \mathrm{~g} / 1 \mathrm{NaCl} .1 \mathrm{ml}$ of the samples was reduced by adding $20 \mathrm{mg} \mathrm{NaBH} 4$ and keeping the samples for $3 \mathrm{~h}$ at room temperature and for a further $3 \mathrm{~h}$ at $4^{\circ} \mathrm{C}$. After dividing the samples in two parts the protein was precipitated with $0.2 \mathrm{ml} 3 \mathrm{~mol} / 1$ trichloroacetic acid and washed twice with $0.6 \mathrm{~mol} / 1$ trichloroacetic acid.

For furosine analysis the trichloroacetic acid precipitate was suspended in $1 \mathrm{ml} 6 \mathrm{~mol} / \mathrm{l} \mathrm{HCl}$, hydrolysed and analysed as described in the methods section. For 5-hydroxymethylfurfuraldehyde analysis the trichloroacetic acid precipitate was suspended in $1 \mathrm{ml} 9 \mathrm{~g} / 1 \mathrm{NaCl}$, and after addition of $0.5 \mathrm{ml} 1 \mathrm{~mol} / 1$ oxalic acid (42) heated for 4.5 hours on a boiling water bath. 5-hydroxymethylfurfuraldehyde was determined both by the thiobarbituric acid method (21), and by HPLC (8). $A=$ before reduction; $B=$ after reduction.

Furosine, nmol/mg protein

\begin{tabular}{|c|c|c|c|c|c|c|c|c|c|}
\hline$\cdot$ & $\mathbf{A}$ & B & $\frac{B \times 100}{A}$ & $\mathbf{A}$ & B & $\frac{B \times 100}{A}$ & $\mathbf{A}$ & B & $\frac{B \times 100}{A}$ \\
\hline $\begin{array}{l}\text { Human albumin } \\
\text { (Behring) }\end{array}$ & 3.4 & $<0.3$ & $<9$ & 0.34 & $<0.02$ & $<6$ & 0.46 & $<0.05$ & $<11$ \\
\hline $\begin{array}{l}\alpha \text {-Globulin } \\
\text { (Cohn-fraction IV) }\end{array}$ & 5.6 & $<0.3$ & $<5$ & 0.46 & 0.11 & 24 & 0.55 & 0.37 & 67 \\
\hline $\begin{array}{l}\beta \text {-Globulin } \\
\text { (Cohn-fraction III) }\end{array}$ & 1.45 & $<0.3$ & $<20$ & 0.14 & 0.09 & 64 & 0.29 & 0.25 & 86 \\
\hline $\begin{array}{l}\boldsymbol{\gamma} \text {-Globulin } \\
\text { (Cohn-fraction II) }\end{array}$ & 2.13 & $<0.3$ & $<14$ & 0.20 & 0.05 & 25 & 0.19 & 0.09 & 47 \\
\hline Transferrin & 4.5 & $<0.3$ & $<7$ & 0.25 & 0.14 & 56 & 0.61 & 0.43 & 70 \\
\hline
\end{tabular}

5-Hydroxymethylfurfuraldehyde, $\mathrm{nmol} / \mathrm{mg}$ protein HPLC method 2-Thiobarbituric acid method 
amine linkages, which result from nonenzymatic Schiff base formation and subsequent Amadori rearrangement. As already detailed in the introduction, sugar is released upon mild acid hydrolysis of the proteins in the form of 5-hydroxymethylfurfural, which can than be determined spectrophotometrically with thiobarbituric acid. This assay is widely used and considered to be specific for nonenzymatically glycosylated proteins. This is however true only for proteins having all their carbohydrate attached via ketoamine linkages, like the glycosylated haemoglobins or glycosylated serum albumin. From our data (tab. 3) it is however clear that glycoproteins whose glycosidic linkages are not reducible with $\mathrm{NaBH}_{4}$ may contribute to 5-hydroxymethylfurfuraldehyde formation under the conditions of acid'hydrolysis. $\mathrm{NaBH}_{4}$-treated controls are therefore always necessary when the 5-hydroxymethylfurfuraldehyde assay is used for the detection of ketoamine linked sugars in proteins.

It should further be noted that the thiobarbituric acid reaction also yields coloured products with compounds other than 5-hydroxymethylfurfuraldehyde (21, 37-40), which might possibly interfere with the spectrophotometric assay. The latter problem can be avoided by measuring 5-hydroxymethylfurfuraldehyde by its absorption at $280 \mathrm{~nm}$ after separation on HPLC (8).

From the foregoing it is clear that the 2-thiobarbituric acid test, though useful for routine analysis of glycosylated haemoglobin and albumin, has limitations if applied for the detection and quantitation of ketoamine linkages of glycoproteins in general. For this purpose the determination of furosine as described here appears to be more suitable, because furosine is only formed from fructose-lysine linkages of proteins upon hydrolysis $(24,25)$. Thus one can obtain specific and quantitative information on the amount of glucose bound to $\epsilon$-amino groups of lysine, the predominant sites for nonenzymatic glucose attachment to proteins. It should be noted that conjugates of glucose with other (terminal) amino groups also yield furosine-like degradation products upon hydrolysis in $6 \mathrm{~mol} / 1 \mathrm{HCl}$ (24), which can be separated and measured by HPLC. Using fructose-valine (prepared according to l.c. (41)) as a standard, we have thus quantified the valine bound glucose in $\mathrm{Hb}_{\mathrm{Ic}}$ (data not shown). Other fructose amino acids which may occur in proteins can equally be determined if the corresponding standards are available.

Apart from its specifity the furosine assay is superior to the assay with 2-thiobarbituric acid with respect to sensitivity. This appears to be of special importance for the detection of nonenzymatically glycosylated proteins which may be obtained in only small amounts from tissues or cells. Thus by measuring furosine, we have been able to demonstrate the occurrence of fructose-lysine in glomerular basement membranes, erythrocyte membranes and plasma membranes of liver cells starting from a few milligrams of the purified preparations (unpublished results).

\section{Acknowledgement}

This work was supported by a grant of the Fritz-Thyssen Stiftung, $\mathrm{Köln}$. The skillful technical assistance of Mr. Hubert Prokop is gratefully acknowledged.

\section{References}

1. Maillard, L. C. (1912), Compt. Rend. Hebd. Séance Acad. Sci 154, 66-68.

2. Allen, D. W., Schroeder, W. B. \& Balog, J. (1958), J. Am. Chem. Soc. 80, 1628-1634.

3. Rahbar, S. (1968), Clin. Chim. Acta 22, 296-298.

4. Bailey, A. J., Robins, S. P. \& Tanner, M. J. A. (1976), Biochim. Biophys. Acta 434, 51-57.

5. Day, J. F., Thorpe, R. \& Baynes, J. W. (1979), J. Biol. Chem. 254, 595-597.

6. Day, J. F., Thornburg, R. W., Thorpe, R. \& Baynes, J. W. (1979), J. Biol Chem. 254, 9394-9400.

7. Dolhofer, R. \& Wieland, O. H. (1979), FEBS Lett. 103 282-286.

8. Wieland, O. H., Dolhofer, R. \& Schleicher, E. (1980), Proc. $10^{\text {th }}$ Congr. Intern. Diabetes Fed. (Waldhäusl, W. K., ed.) pp. 721-727, Excerpta Medica, Amsterdam.

9. Dolhofer, R. \& Wieland, O. H. (1980), Diabetes 29, 417-422.

10. Guthrow, C. E., Morris, M. A., Day, J. F., Thorpe, S. R. \& Baynes, J. W. (1979), Proc. Natl. Acad. Sci. U.S.A. 76, 4258-4261.

11. Stevens, V. J., Rouzer, C. A., Monnier, V. M. \& Cerami, A. (1978), Proc. Natl Acad. Sci. U.S.A. 75, 2918-2922.

12. Bunn, H. F. \& Briehl, R. W. (1970), J. Clin. Invest. 49, 1088-1095.

13. Dolhofer, R. \& Wieland, O. H. (1979), FEBS Lett. 100, $133-136$

14. Weiss, J. B., Lote, C. J. \& Bobinski (1971), Nature New Biol. 234, 25-26.

15. Tanger, M. L., Fairweather, R. \& Gallop, P. M. (1972), Arch. Biochem. Biophys. 151, 137-141.

16. Rosenberg, H., Modrak, J. B., Hassing, J. M., Al-Turk, Walid A., \& Stoks, S. J. (1979), Biochem. Biophys. Res. Comm. 91, 498-501.

17. Hodge, J. E. \& Rist, C. E. (1953), J. Am. Chem. Soc. 75, $316-322$.

18. Holmquist, W. R. \& Schröder, W. A. (1966), Biochemistry 5, 2489-2504.

19. Bunn, H. F., Shapiro, R., McManus, M., Garrick, L., Mc Donald, M., Gallop, P. M. \& Gabbay, K. H. (1979), J. Biol. Chem. 254, 3892-3898.

20. Gottschalk, A. (1952), Biochem. J. 52, 455-460.

21. Keeney, M. \& Basette, R. (1959), J. Dairy Sci. 42, 945-960.

22. Flückiger, R. \& Winterhalter, K. H. (1976), FEBS Lett. $71,356-360$.

23. Erbersdobler, H. \& Zucker, H. (1966), Milchwissenschaft $21,564-568$.

24. Heyns, K., Heukeshoven, J. \& Brose, K.-H. (1968), Angewandte Chemie 15, 627-627.

25. Finot, P. A., Bricout, J., Viani, R. \& Mauron, J. (1968), Experientia 24, 1097-1099. 
26. Finot, P. A. (1973), in: Protein human nutrition (Porter, J. W. G. \& Rolls, B. A. eds.) p. 501, Academic Press, London-New York.

27. Brandt, Andrea (1978), Doctoral Thesis, University of Göttingen.

28. Hofmann, K., Stuız, E., Spühler, G., Yajima, H. \& Schwartz, E. T. (1960), J. Am. Chem. Soc. 82, 3727-3732.

29. Grabar, P. \& Williams, C. A. (1953), Biochim. Biophys. Acta 10, 193-194.

30. Bradford, M. M. (1976), Anal. Biochem. 72, 248-254.

31. Altmann, P. L. \& Dittmar, D. S. (1972), in: Biology Data Book, Vol. 1, p. 446, FASEB, Bethesda, Md. USA.

32. In: Documenta Geigy, Wissenschaftliche Tabellen (J. R. Geigy ed.) Basel, 1960, pp. 167-169.

33. In: Molecular Biology of Human Proteins (1966), (Schultze, H. E. \& Heremans, J. F., eds.) Vol 1, p. 212, Elsevier Publishing Company, Amsterdam, London, New York.
34. Schoos, R., Schoos, B. \& Lambotte, C. (1978), Clin. Chim. Acta 86, 61-65.

35. Dolhofer, R., Städele, A. \& Wieland, O. H. (1977), Klin. Wochenschr. 55, 945-954.

36. Javid, J., Pettis, R. K., Koenig, R. J. \& Cerami, A. (1977), Blood 50 (suppl. 1) 110-110.

37. Baumgartner, W. A., Baker, N., Hill, V. A. \& Wright, E. T. (1975), Lipids 10, 309-311.

38. Warren, L. (1959), J. Biol. Chem. 234, 1971-1975.

39. Waravdekar, V. S. \& Saslaw, L. D. (1959), J. Biol. Chem. 234, 1945-1950.

40. Kuwakara, S. S. (1980), Anal Biochem. 101, 54-60.

41. Heyns, K. \& Breuer, H. (1958), Chem. Ber. 91, 2750-2762.

42. Mc Farland, K. F., Catalano, E. W., Day, J. F., Thorpe, R. S., \& Baynes, J. W. (1979), Diabetes 28, 1011-1014

Prof. Dr. O. Wieland Klin.-chem. Institut Krankenhaus Schwabing Kölner Platz 1

D-8000 München 40 


\section{.}

, 